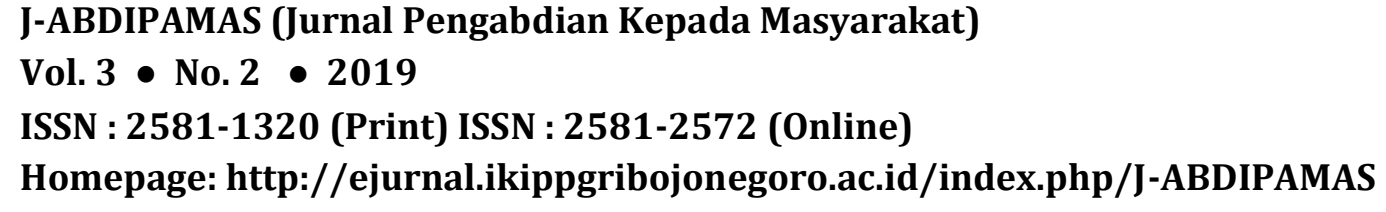

\title{
PELATIHAN PEMBELAJARAN BAHASA INGGRIS UNTUK ANAK USIA DINI PADA GURU RA SE-KABUPATEN PASURUAN
}

\author{
Ana Ahsana El-Sulukiyyah ${ }^{1}$, , Dewi Masitho Istiqomah2, \\ Rasyidah Nur Aisyah ${ }^{3}$, Nur Hari Gede Agustin ${ }^{4}$ \\ ${ }^{1}$ STKIP PGRI Pasuruan. Email: aahsana3@gmail.com \\ 2STKIP PGRI Pasuruan. Email: dewimasithoistiqomah@gmail.com \\ 3STKIP PGRI Pasuruan. Email: ocicyah@gmail.com \\ 4STKIP PGRI Pasuruan, Email: nurhari@gmail.com
}

\begin{abstract}
This is a community service activity which was about English teaching and learning for young learners and its application in classes. The teachers of young learners needs to have knowledge about songs, games and media to teach English which is appropriate with learners' and era's need. Furthermore, this workshop is important to facilitate the teachers in giving the fun English materials. In this activitiy the teacher were trained to make the fun applicated media and the newest English nursery songs and games to be applied in their classes. It is hoped that this activity can facilitate the teachers in Kabupaten Pasuruan about the importantce of English learning for Young Learners, also teachers are hoped to be able to apply the fun and effective teaching learning process which is appropriate to the age and ability of the young learners and also appropriate with this era.
\end{abstract}

Keywords: English teaching, teachers, workshop

\begin{abstract}
ABSTRAK
Berikut adalah kegiatan pengabdian masyarakat yang berfokus pada pembelajaran Bahasa Inggris pada anak usia dini dan bagaimana menerapkannya. Guru-guru RA (sederajat TK) perlu memiliki pengetahuan tentang lagu dan permainan atau media pembelajaran Bahasa Inggris yang sesuai dengan kebutuhan anak dan zaman. Oleh karenanya kegiatan pelatihan ini penting untuk memberikan wadah bagi para guru anak usia dini untuk memberikan pembelajaran Bahasa Inggris dapat menjadi yang menyenangkan. Pada kegiatan ini para guru dilatih untuk membuat media yang menyenangkan, juga diberi bekal tentang lagu-lagu dan permainan yang dapat diaplikasikan pada anak-anak usia dini di kelas. Harapannya, pelatihan ini dapat memberikan pengetahuan baru bagi para guru RA (anak usia dini) di Kabupaten Pasuruan tentang pentingnya pembelajaran Bahasa Inggris pada usia dini, juga agar mereka dapat mengaplikasikan kegiatan pembelajaran yang menyenangkan dan efektif yang sesuai dengan usia dan kemampuan anak dan sesuai dengan perkembangan zaman.
\end{abstract}

Kata Kunci: Guru, Pelatihan, Pembelajaran Bahasa Inggris

\section{PENDAHULUAN}

Bahasa Inggris sebagai salah satu bahasa asing yang dipelajari di Indonesia merupakan bahasa internasional yang pelaksanaan pembelajarannya mendapatkan perhatian lebih di dunia pendidikan. Bahasa inggris secara resmi mulai masuk pada kurikulum sekolah dasar pada 1994 
(Jazuly, 2006) dan kemudian diikuti dengan program-program pembelajaran Bahasa Inggris pada tingkat pembelajar yang lebih rendah seperti TK dan PAUD (Pendidikan Anak Usia Dini). Walaupun pada masa sekarang Bahasa Inggris bukan lagi menjadi mata pelajaran wajib di Sekolah Dasar melainkan hanya muatan lokal, Bahasa Inggris masih dianggap penting untuk dikenalkan pada anak usia dini (AUD) di tingkat rendah seperti TK/RA dan PAUD (Masruroh, Ainiyah, \& Hidayah, 2018). Pentingnya perkenalan pembelajaran Bahasa Inggris ini tentunya akan berdampak pada anak usia dini tersebut. Seperti kita ketahui bahwa anak usia dini adalah anak yang dalam masa tumbuh kembang pola pikir dan jasmaninya (Jazuly, 2014). Menurut UUSPN No.20/2003, pasal 28 ayat 1 (Jazuly, 2014) anak usia dini adalah anak yang berada pada

usia 0 - 6 tahun. Sedangkan para ahli mengatakan bahwa anak yang berusia 0 - 6 tahun dinamakan PAUD. Anak-anak pada usia ini mempunyai masa emas untuk belajar dan mengembangkan kebahasaan. Anak pada usia dini mempunyai ketajaman ingatan melalui proses menyimak, melihat bahkan memimpikannya (Besral, 2010). Penanaman dan pengenalan Bahasa Inggris menjadi awal terpatoknya pengetahuan Bahasa Inggris mereka, ketika Bahasa inggris dikenalkan sejak dini. Pengenalan Bahasa Inggris untuk AUD (anak usia dini) tentunya bukan tentang skill atau kemampuan berbahasa melainkan tentang komponen kebahasaan tersebut. Komponen bahasa meliputi : vocabulary, pronunciation dan spelling (Ma'mun, 2010).

Pembelajaran Bahasa Inggris untuk anak usia dini masih menjadi perdebatan dikarenakan Bahasa Inggris merupakan bahasa asing, dikarenakan oleh pendapat bukan berarti ketika ditanamkan semakin dini, hasilnya akan semakin baik (Mukminatun, 2008) akan tetapi pendapat ini kemudian dibantah dalam Yamin (2017) yang menyatakan bahwa dengan memperhatikan konsep-konsep dasar perkembangan kemampuan berbahasa anak, penanaman bahasa kedua atau bahasa asing dapat dilakukan pada anak usia dini. Selanjutnya (Yamin, 2017) menuturkan bahwa penerapan metode yang benar dalam pembelajaran Bahasa Inggris akan mempengaruhi kesiapan dan kemampuan anak untuk mempelajarinya, metode-metode yang dapat dilakukan adalah sebagai berikut : (a) metode langsung/ Direct Method, (b) metode Berlitz, (c) metode alami/ natural method, (d) metode percakapan/ conversation method, (e) metode phonetic atau memperkenalkan suara-suara dalam pelafalan bahasa inggris, (f) metode Practice-Theory, (g) metode membaca, (h) metode bicara lisan, (i) metode praktek pola kalimat. Dengan metodemetode di atas, diharapkan anak usia dini tidak merasa bosan dengan pemaparan bahasa asing dalam pembelajaran mereka, terlebih karen apentingnya bahasa asing untuk dipelajari dan dikembangkan sejak dini.

El-Sulukiyyah (2018) mengungkapkan terjadinya kesalahan melafalkan kata atau kalimat (pronunciation)dalam Bahasa Inggris yang biasa terjadi pada usia dewasa atau mahasiswa disebabkan oleh kurangnya pengetahuan Bahasa Inggris sejak kecil dan kadangkala kesalahan ini sulit dibetulkan atau menjadi terfosilisasi. Hal ini bisa dihindari sejak dini jika guru mampu menghadirkan metode phonetic tersebut diatas pada pembelajaran Bahasa Inggris untuk anak usia dini. Sejak dini anak diperkenalkan dengan suara atau pelafalan yang benar, mengingat pelafalan dalam bahasa inggris tidak selalu sama dengan tulisan. Hal ini bisa dilakukan dengan cara memberikan irama-irama dalam kata yang pelafalannya mirip seperti cat-pat-bat-hat atau hockey-pockey-cookey-dockey. Sehingga saat bertumbuh atau menjadi pembelajar dewas, anakanak tersebut sudah mempunyai bekal untuk melafalkan kata0kata dengan baik. Lebih lanjut ElSulukiyyah (2017) menjelaskan kesalahan pada penggunaan kata atau diksi juga masih menjadi kesalahan umum pada pembelajara Bahasa Inggris dewasa. Hal ini dapat dihindari dari penanaman metode practice-theory diatas sehingga anak-anak yang nati akan tumbuh dan 
berkembang dapat mengingat bagaimana seharusnya mereka membuat kalimat atau merangkai kalimat dengan benar.

Pembelajaran Bahasa Inggris sebagai bahasa asing pun akan terkesan menarik oleh anak usia dini jika dikemas dalam kemasan yang menarik. Materi pembelajaran Bahasa inggris, baik itu berkaitan dengan vocabulary atau spelling harus bersifat gembira atau fun dan interaktif, selain itu nuansa yang dibawa oleh guru harus dengan nuansa yang gembira sehingga anak usia dini tidak merasa dibebabi dengan pembelajaran bahasa asing yang jauh berbeda dengan bahasa utamanya, melainkan mereka akan merasa senang dan secara tidak sadar sudah belajar tentang bahasa asing (Ma'mun, 2010). Metode nyanyian atau songs merupakan metode yang paling sering digunakan (Adnyani, 2018) dalam nyanyian, pikiran dan perasaan akan tercurahkan dan akan mudah diingat. Dalam nyanyian terdapat jenis bahasa yakni (a) bahasa emosi, nyanyian yang diajarkan pada anak dapat mengungkapkan berbagai emosi misalnya : senang, sedih, kagum, haru dan lucu, (b) bahasa nada, nada dapat membuat nyanyian tersebut dapat didengar dapat dikomunikasikan dan dinyanyikan, (c) bahasa gerak, gerak yang diungkapkan pada nyanyian terdapat pada irama, anak-anak usia dini selalu mempraktekkan nyanyian dengan gerak yang dapat menerjemahkan arti nyanyian tersebut (Khairani, 2010). Asmin (2013) menambahkan bahwa pembelajaran bahasa asing juga baik dengan metode pengalaman langsung atau direct method sehingga anak usia dini tidak terbebani dengan suasana belajar yang menegangkan tetapi langsung mempraktekkan apa yang didengar dan dilihatnya.

Oleh karena itu pembelajaran Bahasa Inggris pada Usia Dini sangat diperlukan untuk mencetak generasi yang siap menghadapi era milenial saat ini. Sehingga saat mereka tumbuh dan berkembang menjadi pembelajar dewas, mereka sudah mempunyai bekal dan pengetahuan tentang bahasa asing dalam hal ini Bahasa Inggris. Guru-guru pun dibekali dengan pelatihapelatihan pembelajaran Bahasa Inggris yang menyenangkan dan tidak membosankan. Kegiatan pengabdian kepada masyarakat ini mempunyai fokus pada pelatihan pembelajaran Bahasa Inggris untuk guru-guru Roudhotul Athfal atau setara TK sehingga guru-guru mendapat bekal bagaimana pembelajaran Bahasa Inggris yang fun, atraktif, aplikatif dan kreatif untuk diaplikasikan pada anak didiknya para anak usia dini demi mendapat kesiapan kemampuan berbahasa terlebih penanaman Bahasa Inggris sejak dini.

\section{METODE PELAKSANAAN}

Kegiatan pengabdian kepada masyarakat ini dilaksanakan di Gedung Serbaguna STKIP PGRI Pasuruan dengan peserta 200 Guru RA (Raudhotul Athfal) yang tergabung dalam Ikatan Guru Raudhotul Athfal (IGRA) se Kabupaten Pasuruan pada tanggal 29 November 2018. Kegiatan ini diikuti oleh Guru RA dari setiap kecamatan di Kabupaten Pasuruan dengan rincian 10 guru dari setiap Kecamatan. Metode pelatihan ini menggunakan metode drill practice dan ceramah dengan menggunakan media visual dan audio visual. Media visual meliputi media-media pembelajaran Bahasa Inggris, mulai dari media angka, media realia hewan dan buah, media barang nyata dan gambar. Sedangkan media audio visual meliputi video lagu/songs dan audio lagu/songs. Teknik pengumpulan data dilakukan dengan dokumentasi, observasi, penyebaran angket, dan wawancara. Instrumen yang digunakan adalah angket dan tes. Pada awal kegiatan pelatihan, peserta diberikan beberapa pertanyaan/tes tentang pentingnya pembelajaran Bahasa Inggris 
untuk anak usia dini. Kemudian peserta diberikan pengetahuan tentang pembelajaran anak usia dini (metode ceramah) dan pemratekkannya (metode drill practice). Pelatihan ini menekankan pada pembelajaran kosakata Bahasa Inggris (vocabulary) menggunakan permainan (games) dan lagu (songs) serta bagaimana membuat media atau alat peraga pembelajaran Bahasa Inggris yang sesuai untuk anak usia dini.

\section{HASIL DAN PEMBAHASAN}

Hasil dari kegiatan pengabdian kepada masyarakat ini menunjukkan bahwa kegiatan ini berjalan dengan lancar dimulai pukul 08.00 pagi sampai dengan 17.00 sore hari. One day service pada pelatihan ini cukup berjalan dengan baik, para guru yang datang untuk pelatihan terlihat antusias dan menikmati kesempatan mereka berlatih pembelajaran Bahasa Inggris yang baru dengan games dan songs yang baru sehingga dapat diaplikasikan pada anak didiknya ketika telah kembali ke sekolah.

Terdapat 4 pengabdi pada kegiatan ini dengan beberapa tugas yang berbeda yakni :

1. Menyebarkan dan menganalisa angket tentang pembelajaran Bahasa Inggris di sekolah asal.

2. Memberikan materi tentang pentingnya pembelajaran Bahasa Inggris untuk anak usia dini.

3. Memberikan pelatihan tentang membuata media yang baik dan cocok untuk pembelajaran Bahasa Inggris yang difokuskan pada vocabulary, pronunciation and spelling.

4. Memberikan pelatihan dan praktek tentang gerak, lagu dan permainan yang baru dan inovatif untuk diaplikasikan pada anak usia dini di sekolah para guru yang mengikuti pelatihan.

Pada awal pelatihan, para guru diberikan angket untuk mengetahui bagaimana para guru memberikan pengajaran Bahasa Inggris kepada anak didiknya (anak usia dini). Berikut adalah hasil jawaban para guru pada angket yang disebarkan :

Tabel 1. Hasil jawaban angket tentang pembelajaran Bahasa Inggris di sekolah

\begin{tabular}{|c|c|c|}
\hline \multirow{2}{*}{ Indikator } & \multicolumn{2}{|c|}{ Persentase jawaban } \\
\cline { 2 - 3 } & Ya & Tidak \\
\hline Terdapat pelajaran Bahasa Inggris di sekolah tempat mengajar & $100 \%$ & $32 \%$ \\
\hline Terdapat alat peraga untuk pelajaran Bahasa Inggris & $68 \%$ & $13 \%$ \\
\hline Mengetahui cara mengajar dan memperkenalkan Bahasa Inggris & $87 \%$ & $7 \%$ \\
\hline Mengajarkan Bahasa Inggris dengan nyanyian & $93 \%$ & $9 \%$ \\
\hline Mengajarkan Bahasa Inggris dengan permainan & $91 \%$ & $55 \%$ \\
\hline Mengetahui informasi tentang pembaruan dalam pengajaran & $45 \%$ & $58 \%$ \\
\hline Bahasa Inggris & & $2 \%$ \\
\hline
\end{tabular}


Dari hasil diatas dapat disimpulkan bahwa pengajaran Bahasa Inggris telah dilakukan di sekolah-sekolah tingkat Taman Kanak-kanak atau Raudhotul Athfal di Kabupaten Pasuruan, namun sistem dan metode pembelajarannya masih perlu dibekali dengan pelatiha-pelatihan untuk para guru sehingga dapat menjadi pembelajaran yang aplikatif. Setelah mengisi angket para guru diperkenalkan dengan pembahasan mengenai pentingnya pembelajaran Bahasa Inggris pada anak usia dini. Terdapat sesi diskusi dalam kegiatan ini, sesi tanya jawab pun dilalui dengan lancar. Terdapat beberapa pertanyaan mendasar yang disampaikan oleh para guru yakni tentang bagaimana seharusnya memberikan contoh yang benar terhadap pelafalan suatu kata. Misalnya kata hair tertulis h-a-i-r tetapi dibaca /hə:/, bagaimana memberi pengertian kepada anak usia dini yang baru mengenal huruf dan baru bisa membaca. Pada El-Sulukiyyah (2018) disebutkan bahwa penggunaan phonetic symbol dianjurkan dalam pembelajaran pelafalan atau pronunciation. Guru seyogyanya mengetahui simbol-simbol fonetik yang dipakai dalam pelafalan bahasa inggris untuk kemudian diaplikasikan dengan metode repeat after me atau direct method. Dengan mengetahui simbol-simbol suara yang dipakai dalam Bahasa Inggris misalnya cat yang dilafalkan menjadi /kæt/ maka guru akan dapat memberikan contoh pelafalan yang benar sehingga pelafalan yang benar tersebut akan dapat dipahami dan diingat oleh anak usia dini tersebut. Metode yang baik untuk anak usia dini dalam mengucapkan dan melafalkan kata adalah repeat after me method, metode ini dapat dikembangkan melalui lagu-lagu yang menyenangkan untuk anak (Miranti, Engliana, \& Hapsari, 2015). Lagu-lagu yang lumrah didengar anak dapat digubah menjadi lagu-lagu berbahasa inggris, misalnya lagu Pelangi, guru dapat menggubahnya menjadi lagu Rainbow dengan lirik sebagai berikut:

\section{Oh rainbow oh rainbow How beautiful you are Red yellow and green On the blue blue sky Your painter is so great Tell me who he is Oh rainbow oh rainbow The creation of God}

Terlihat dalam lagu tersebut terdapat beberapa kosakata, yakni macam warna, kemudian kosakata terkait warna yakni pelangi dan awan. Juga lagu tersebut tidak asing ketika dinyanyikan dengan nada lagu Pelangi yang sudah dikela anak. Guru sebaiknya memberikan hal baru yang penerapannya tidak asing dilihat atau didengar anak. Tidak harus bagi guru memberikan lagu asli Inggris untuk memberikan contoh pelafalan yang tepat tetapi lagu-lagu anak Indonesia bisa digubah menjadi lagu berbahasa inggris yang tentunya menyenangkan dan aplikatif untuk disajikan pada anak-anak usia dini. 
Gambar 1. Kegiatan Tanya Jawab dan Diskusi

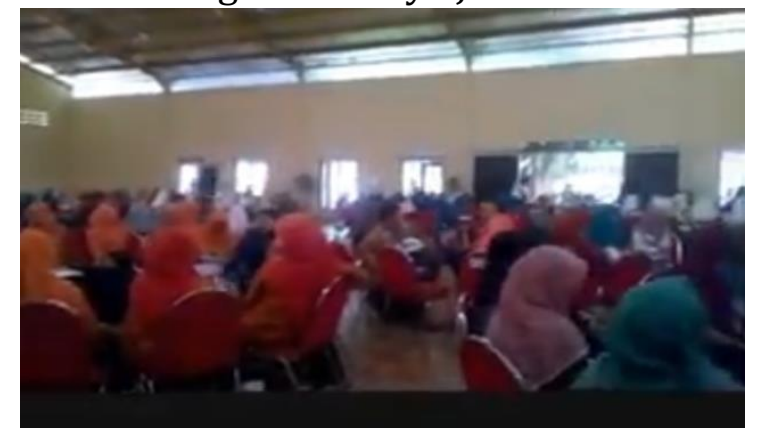

Setelah kegiatan diskusi dan tanya jawab, para pengabdi memberikan kegiatan lanjutan yakni membuat media pembelajaran yang cocok untuk anak usia dini. Media yang menjadi fokus saat pelatihan adalah, media numbers, colors dan animals. Pada media numbers para pengabdi memberikan contoh membuat media dari bahan habis pakai seperti kalender bekas, kardus bekas dan kertas warna warni yang sudah tidak dipakai. Angka-angka pada kalender dapat digunakan menjadi flashcard warna-warni yang menarik, kreatifitas tempel menempel akan tampak disini. Kemudian untuk media colors, kain-kain perca warna-warni dapat dibuat menjadi media baru yang kreatif untuk memperkenalkan warna kepada anak usia dini. Untuk animals, media baru yang dibuat berupa gambar pasangan mata atau pasangan kaki hewan-hewan yang dimaksud. Misalnya di kartu (media yang dibuat oleh para guru) terdapat kata FROG, maka, dibalik kartu tersebut tertempel gambar sepasang mata katak. Hal ini memungkinkan untuk para guru menggunakan media tersebut selain untuk memperkaya vocabulary siswa juga untuk menjadikannya sebagai permainan tebak-tebakan yang menyenangkan.

Gambar 2. Kegiatan Membuat Media

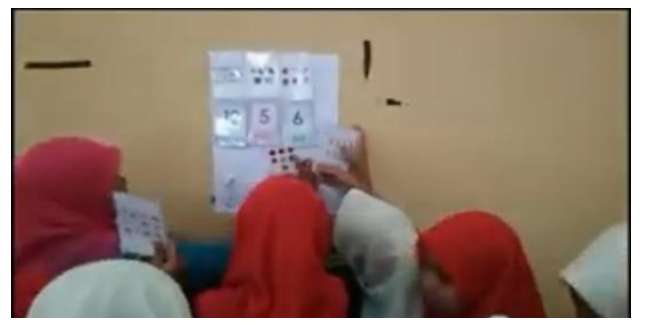

Kegiatan terakhir merupakan kegiatan praktek permainan dan lagu. Pada geiatan praktek ini, peserta dibagi menjadi 10 kelompok besar, dan 20 kelompok kecil. Ketika menjadi kelompok besar, setiap kelompok dibagikan kartu-kartu atau gambar-gambar. Ketika menjadi kelompok-kelompok kecil peserta diberikan lagu-lagu berbahasa inggris yang aplikatif untuk diajarkan pada anak didiknya. Permainan-permainan yang dikenalkan dalam pelatihan ini antara lain : guess me, let's whisper, go round dan get me. Permainan guess me adalah permainan tebak-tebakan, para peserta diberikan kartu dan menebak nama hewan/tumbuhan/buah yang tertera di kartu. Peserta yang bertindak sebagai guru atau yang memberikan permainan, menunjukkan potongan gambar dan menjelaskan kepada peserta lain yang menjadi siswanya. Ketika potongan gambar tersebut ditunjukkan maka peserta lain harus menebak gambar apakah itu tentunya harus sesuai dengan penjelasan dari sang guru. Permainan kedua yaitu let's whisper atau permainan berbisik. Peserta dibagi menjadi beberapa kelompok kecil, lima sampai tujuh 
orang dengan kuantitas yang sama dengan kelompok lain, dan dibisikkan kata, kemudian melanjutkan berbisik pada temannya sampai akhir barisan, seorang teman yang ada dalam akhir barisan menuliskan di papan kata apa yang telah didengarnya. Tentunya apabila diaplikasikan pada anak usia dini, permainan ini akan menyenangkan dan kolaboratif. Anak usia dini merupakan anak yang tumbuh kembang kebahasaannya sedang tumbuh pesat, mereka suka dengan apa yang didengar dan dilihatnya serta menyukai kegiatan dengan suasana yang menyenangkan ((Yamin, 2017).

Praktek permainan selanjutnya adalah permainnan go round dimana para peserta diharuskan berdiri dalam sebuah lingkaran dan bersama-sama menyanyikan lagu ABC atau 123 sambil terus berpegangan tangan dan antara tangan satu dan yang lainnya bertepu seperti dalam permainan domikado, ketika lagu habis, tangan peserta yang terkena tepukan akan menjadi tumbal. Peserta tersebut harus maju ke tengah lingkaran dan menghitung banyak peserta lain dalam lingkaran tersebut dengan bahasa inggris. Permainan ini dapat dimodifikasi dengan berbagai macam kebutuhan, peserta yang kena tepukan bisa juga diberi pertanyaan misalnya "mention 3 animals!" atau peserta yang kena tepukan diharuskan maju ke tengah lingkaran dan memimpin peserta lain untuk bernyanyi. Hal ini meningkatkan keingintahuan dan daya saing peserta. Terakhir, permainan yang dikenalkan dalam pelatihan ini adalah get me. Permainan ini adalah permainan fisik untuk menangkap peserta yang tidak mendapat pasangan. Misalnya terdapat 12 orang, setiap orang diberi kartu berpasangan, goose-goose, mouse-mouse dan seterusnya, begitu kartu dibalik dan salah seorang diantaranya mendaoat kartu kosong, maka dialah yang harus dikejar. Tetapi peserta lain harus berkumpul dahulu dengan para peserta yang mempunyai kartu yang sama, setelah dirasa pemegang katu kosong sudah ditemukan maka peserta lain harus mengejarnya dan mendapatkannya dalam hitungan 20 detik.

Mukminatun (2008) mengatakan pembelajaran bahasa yang disesuaikan dengan karakteristik peserta didik dan karakteristik perkembangan kebahasaannya akan berdampak pada meningkatnya kulitas kebahasaan peserta didik itu sendiri. Untuk mencapai hal itu para guru diberikan pembekalan dan pelatihan bagaiman memberikan pengetahuan dini tentang Bahasa Inggris tetapi tidak terkesan membebani pada anak usia dini. Pembelajaran-pembelajaran Bahasa Inggris pun harus membuat anak tersebut terlibat dengan apa yang didengarnya dan dilihatnya, sehingga penanaman Bhaasa Inggris dapat menjadi bekal mereka hingga mereka menjadi pembelajar dewasa.

\section{SIMPULAN}

Kegiatan Pengabdian Kepada Masyarakat ini merupakan upaya pengabdi untuk mengenalkan bagaimana seharusnya pembelajaran Bahasa Inggris untuk anak usia dini diterapkan. Capaian daripada kegiatan ini adalah aplikasi pembelajaran Bahasa Inggris yang fun, inovatif dan kreatif dapat dibawa ke sekolah asal para guru setelah mendapatkan pelatihan. Para guru juga diharapkan bertambah pengetahuannya tentang permainan, lagu dan media yang dapat diaplikasikan dalam pembelajaran Bahasa Inggris di sekolahnya. Selain itu para guru juga dapat mengembangkan kreatifitasnya setelah 
mendapatkan pelatihan ini, baik pada pembuatan media ajar dari bahan habis pakai, menggunakan lagu-lagu yang sering didengar siswa dan disadur dalam Bahasa Inggris atau mempraktekkan permainan-permainan modifikasi baru yang dapat menanamkan bahwa Bahasa Inggris adalah pembelajaran yang menyenangkan, memberikan suasan gembira dan melibatkan setiap aktifitas siswa yang dalam hal ini adalah anak usia dini.

\section{UCAPAN TERIMA KASIH}

Ucapan terima kasih penulis sampaikan kepada Program Studi Pendidikan Bahasa Inggris dan UPPM STKIP PGRI Pasuruan yang telah memberikan wadah bagi para pengabdi untuk melakukan kegiatan pelatihan pembelajaran Bahasa Inggris untuk anak usia dini. Penulis juga berterima kasih kepada Ketua IGRA Kabupaten Pasuruan dan Kettua IGRA Kecamatan se Kabupaten Pasuruan atas kerjasamanya dalam mengikuti pelatihan dan kegiatan Pengabdian Kepada Masyarakat ini.

\section{DAFTAR RUJUKAN}

Adnyani, N. W. S. (2018). Metode Total Physical Response ( TPR ) Untuk Pengembangan Kemampuan Mendengarkan dalam Pembelajaran Bahasa. Pratama Widya, 3(2), 2836.

Asmin, A. I. (2013). Pengenalan dan Peningkatan Minat Anak Usia Dini untuk Mempelajari Bahasa Inggris. Prosiding Seminar Nasional, 02, 191-197.

Besral. (2010). Pembelajaran Bahasa Inggris Untuk Anak-anak. Ta'dib, 13(1), 10-17.

El-Sulukiyyah, A. A. (2017). The Grammatical Errors of Spoken English Produced by the First Semester Students of Intensive Course. International Conference on Islamic Education (ICIED) 2017, (2), 380-385.

El-Sulukiyyah, A. A. (2018). Fixing Students' Pronunciation Through Phonetic TRanscription. Jurnal Edukasi Dan Sosial, 9(2), 97-105.

Jazuly, A. (2006). Peran Bahasa Inggris Pada Anak Usia Dini. Jurnal Pendidikan Dompet Dhuafa, 6(1), 33-40.

Jazuly, A. (2014). Pendidikan Bahasa Inggris Pada Anak Usia Dini. Didaktika, 10(2), 3342.

Khairani, A. I. (2010). Pendidikan Bahasa Inggris Untuk Anak Usia Dini. Medan.

Ma'mun, N. (2010). Pembelajaran Bahasa Inggris Bagi Anak Sekolah Dasar Lewat Lagu dan Permainan. Retrieved September 26, 2019, from publikasi ilmiah ums website: https://www.google.com/url?sa=t\&source=web\&rct=j\&url=https://publikasiilmia h.ums.ac.id/bitstream/handle/11617/1704/Nadiah

Masruroh, L., Ainiyah, M., \& Hidayah, B. (2018). Pelatihan Pengajaran Bahasa Inggris Usia Dini bagi Guru-Guru Bahasa Inggris di PAUD-TK-MI. JPP IPTEK, 2(1), 51-54.

Miranti, I., Engliana, \& Hapsari, F. S. (2015). Penggunaan Media Lagu Anak-Anak Dalam Mengembangkan Kemampuan Kosakata. Faktor Jurnal Ilmiah Kependidikan, II(2), 167-173.

Mukminatun, S. (2008). Teknik Pengajaran Bahasa Inggris untuk Anak. Retrieved September 26, 2019, from Teknik Pengajaran Bahasa Inggris untuk Anak website: id.scribd.com/doc/123558545/Teknik-Pengajaran-Bahasa-Inggris-Untuk-Anak

Yamin, M. (2017). Metode Pembelajaran Bahasa Inggris Di Tingkat Dasar. Jurnal Pesona Dasar, 1(5), 82-97. 